\title{
THE STATUS OF PARTICIPATION IN EXTRACURRICULAR SPORT TRAINING OF STUDENTS IN SOC TRANG PROVINCE, VIETNAM
}

\author{
Dang Minh Thanh ${ }^{1}$, \\ Tran Nam Giao', \\ Nguyen Quang Vinh ${ }^{3 \mathrm{i}}$ \\ ${ }^{1} \mathrm{PhD}$, Can Tho University, \\ Vietnam \\ ${ }^{2}$ Viet Nam National University, \\ Ho Chi Minh City Center for Sport, \\ Vietnam \\ ${ }^{3} \mathrm{PhD}$, Ho Chi Minh City University of \\ Physical, Education and Sports, \\ Vietnam
}

\begin{abstract}
:
The method of sociological investigation is used in the article to survey students' opinions at colleges in Soc Trang province and provided information on the status of participation in extracurricular sports of students at colleges in Soc Trang province by gender, ethnicity and purpose.
\end{abstract}

Keywords: exercise, extracurricular sports, students, Soc Trang

\section{Introduction}

Extracurricular sport activities are very important for the students' mental and physical health training after hard working time. In addition, these activities also give students a healthy spiritual life and create excitement and passion in learning and research. Organizing extracurricular sport activities in schools to encourage students who are voluntarily participate in practicing sports and forming a habit of regular physical exercise for students is a requirement of the Ministry of Education and Training for schools [1].

Vietnam's Physical education and Sport Development Strategy to 2020 has set out important tasks including the task of developing extracurricular sport activities such as building various types of school sport clubs, encouraging students to spend 2-3 hours per

i Correspondence: vinhqn@upes.edu.vn 
week to participate in extracurricular sport activities at clubs or sports classes, consolidating and developing a system of sport competitions suitable for each school level, region and locality [6, p.9,12]. Therefore, it is very necessary to spend time practicing sports regularly every day according to a method suitable for health and hobby. Studies in many countries show that students participating in physical activities for one hour or more a day are appropriate and if they only took two hours of exercise per week is not enough [4]. From the above reasons, I conducted research on the topic "The status of participation in extracurricular sport training of the students in Soc Trang province".

\section{Research methods}

Synthesis and analysis of documents, interviews and statistical math. Interviewees: 1024 students (381 males, 643 females) in colleges in Soc Trang province.

\section{Research results}

The topic of assessing the reality of participating in extracurricular sport training of students at colleges in Soc Trang province, the topic of surveying students by gender and school and the purpose of students when participating in extracurricular sport activities.

\subsection{The reality of students at colleges in Soc Trang province participating in exercising extracurricular sports}

The interview results of students participating in extracurricular sport training by gender, ethnicity and colleges in Soc Trang province are presented in Table 1.

Table 1: The reality of the students participating in training extracurricular sports by gender and by school $(n=2024)$

\begin{tabular}{|c|c|c|c|c|c|c|c|c|c|}
\hline \multirow{2}{*}{\multicolumn{2}{|c|}{$\begin{array}{l}\text { School } \\
\text { Extracurricular } \\
\text { sports Gender }\end{array}$}} & \multicolumn{2}{|c|}{$\begin{array}{c}\text { Soc Trang Teacher's } \\
\text { Training College }\end{array}$} & \multicolumn{2}{|c|}{$\begin{array}{c}\text { Soc Trang } \\
\text { Community College }\end{array}$} & \multicolumn{2}{|c|}{$\begin{array}{c}\text { Soc Trang } \\
\text { Vocational College }\end{array}$} & \multicolumn{2}{|c|}{ Total } \\
\hline & & 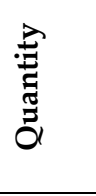 & 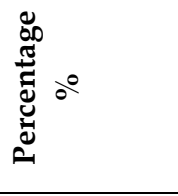 & 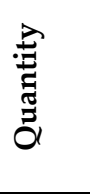 & 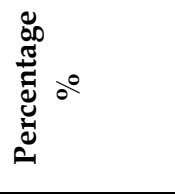 & 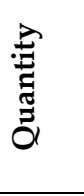 & 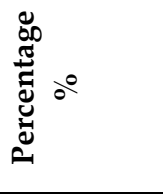 & 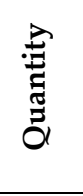 & 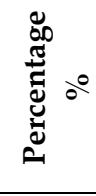 \\
\hline \multirow[t]{3}{*}{ Usually } & Male & 60 & 5.86 & 8 & 0.78 & 36 & 3.52 & 104 & 10.16 \\
\hline & Female & 71 & 6.93 & 10 & 0.98 & 10 & 0.98 & 91 & 8.89 \\
\hline & Total & 131 & 12.79 & 18 & 1.76 & 46 & 4.49 & 195 & 19.04 \\
\hline \multirow[t]{3}{*}{ Sometimes } & Male & 48 & 4.69 & 23 & 2.25 & 67 & 6.54 & 138 & 13.48 \\
\hline & Female & 292 & 28.52 & 50 & 4.88 & 26 & 2.54 & 368 & 35.94 \\
\hline & Total & 340 & 33.20 & 73 & 7.13 & 93 & 9.08 & 506 & 49.41 \\
\hline \multirow[t]{3}{*}{ Never } & Male & 12 & 1.17 & 29 & 2.83 & 98 & 9.57 & 139 & 13.57 \\
\hline & Female & 73 & 7.13 & 78 & 7.62 & 33 & 3.22 & 184 & 17.97 \\
\hline & Total & 85 & 8.30 & 107 & 10.45 & 131 & 12.79 & 323 & 31.54 \\
\hline \multirow[t]{3}{*}{ Total } & Male & 120 & 11.72 & 60 & 5.86 & 201 & 19.63 & 381 & 37.21 \\
\hline & Female & 436 & 42.58 & 138 & 13.48 & 69 & 6.74 & 643 & 62.79 \\
\hline & Total & 556 & 54.30 & 198 & 19.34 & 270 & 26.37 & 1024 & 100.00 \\
\hline
\end{tabular}


The interview results of students participating in extracurricular sport training by school:

The total of 1024 students in Soc Trang province were interviewed (Teacher's Training college 556 students accounting for 54.30\%, Community College 198 students accounting for $19.34 \%$, Vocational College 270 students accounting for $26.37 \%$ ). The number of 1024 students, there are 701 students participating in extracurricular sports training, accounting for $68.45 \%, 323$ students never participating in practice accounting for $31.55 \%$. Out of 701 students in Soc Trang province participated in extracurricular sports training (Teacher's Training College 471 students accounting for 45.99\%, Community College 91 students accounting for 8.89\%, Vocational College 139 students accounting for 13.57\%); out of 323 Soc Trang students who did not participate in extracurricular sport training (85 Teacher's Training college students accounting for $8.30 \%, 107$ Community College students accounting for 10.45\%, 131 vocational colleges accounting for $12.79 \%$ ).

Out of 701 students $(68.45 \%)$ in Soc Trang province participated in extracurricular sport training, the students who exercised regularly including 195 students accounting for $19.04 \%$ (Teacher's Training college 131 students accounting for $12.79 \%$, Community College 18 students accounting for $1.76 \%$, Vocational college 46 students accounting for $4.49 \%$ ) and the students who sometimes exercised including 506 students accounting for 49.41\% (Teacher's Training college 340 students accounting for 33.20\%, Community College 73 students accounting for $7.13 \%$, Vocational college 93 students accounting for $9.08 \%)$.

\subsection{Results of interviewing students participating in extracurricular sport training by gender}

Out of the total 1024 students interviewed in Soc Trang province, there are 381 male students accounting for 37.21\% (Teacher's Training college 120 students accounting for $11.72 \%$, Community college 60 students accounting for 5.86\%, Vocational college 131 students accounting for $12.79 \%$ ), and there are 643 female students accounting for $62.79 \%$ (Teacher's Training College 436 students accounting for $42.58 \%$, Community College 138 students accounting for $13.48 \%$, Vocational College 69 students accounting for $6.74 \%$ ).

Of the 701 students $(68.45 \%)$ participating in practicing extracurricular sports, there are 242 male students, accounting for 23.64\% (Teacher's Training college 108 students accounting for $10.55 \%$, Community college 31 students accounting for $3.03 \%$, Vocational college 107 students accounted for $10.06 \%$ ), and there are 459 female students accounting for $44.83 \%$ (Teacher's Training college 363 students accounting for $35.45 \%$, Community college 60 students accounting for 5.86\%, Vocational College 36 students accounting for $3.52 \%$ ). Thus, in 701 students participating in practicing extracurricular sports, the percentage of female students $(44.83 \%)$ is higher than the rate of male students (23.64\%). Among 242 male students participating in extracurricular sport training, the students who practiced regularly consisting of 104 accounting for 10.16\%, 138 students practice occasionally accounting for $13.48 \%$. Out of 459 female students who practice 
regularly consisting of 91 students accounting for $8.89 \%, 368$ students practice occasionally accounting for $35.94 \%$.

The number of 323 students (31.55\%) who had never took part in practicing extracurricular sports, there were 139 males accounting for 13.57\% (Teacher's Training college 12 students accounting for $1.17 \%$, Community college 29 students accounting for $2.83 \%$, Vocational college 98 students accounting for 9.57\%), 184 females accounting for $17.97 \%$ (Teacher's Training college 73 students accounting for $7.13 \%$, Community College 78 students accounting for $7.62 \%$, Vocational College 33 students accounting for $3.22 \%$. Thus, among 323 students who never took part in practicing curricular sports, the proportion of female students (17.97\%) was higher than that of male students (13.57). \%). The percentage of students in Soc Trang province participating in the extracurricular sports is shown in Figure 1.

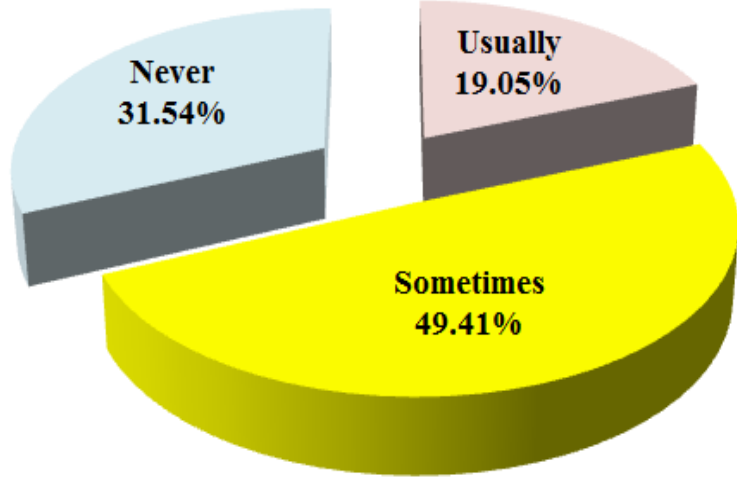

Figure 1: Percentage of students in Soc Trang province participating in extracurricular sports

Table 2: Students participating in extracurricular sports by ethnicity and school ( $\mathrm{n}=1024)$

\begin{tabular}{|c|c|c|c|c|c|c|c|c|c|}
\hline \multirow{2}{*}{\multicolumn{2}{|c|}{$\begin{array}{l}\text { School } \\
\text { Extracurricular } \\
\text { Sports Gender }\end{array}$}} & \multicolumn{2}{|c|}{$\begin{array}{c}\text { Soc Trang } \\
\text { Teacher's Training } \\
\text { College } \\
\end{array}$} & \multicolumn{2}{|c|}{$\begin{array}{l}\text { Soc Trang } \\
\text { Community } \\
\text { College } \\
\end{array}$} & \multicolumn{2}{|c|}{$\begin{array}{c}\text { Soc Trang } \\
\text { Vocational } \\
\text { College } \\
\end{array}$} & \multicolumn{2}{|c|}{ Total } \\
\hline & & Quantity & $\%$ & Quantity & $\%$ & Quantity & $\%$ & Quantity & $\%$ \\
\hline \multirow[t]{3}{*}{ Usually } & Kinh & 77 & 7.52 & 18 & 1.76 & 40 & 3.91 & 135 & 13.18 \\
\hline & Ethnics & 54 & 5.273 & 0 & 0.00 & 6 & 0.586 & 60 & 5.859 \\
\hline & Total & 131 & 12.79 & 18 & 1.76 & 46 & 4.49 & 195 & 19.04 \\
\hline \multirow[t]{3}{*}{ Sometimes } & Kinh & 226 & 22.07 & 31 & 3.03 & 27 & 2.64 & 284 & 27.73 \\
\hline & Ethnics & 114 & 11.13 & 42 & 4.10 & 66 & 6.45 & 222 & 21.68 \\
\hline & Total & 340 & 33.20 & 73 & 7.13 & 93 & 9.08 & 506 & 49.41 \\
\hline \multirow[t]{3}{*}{ Never } & Kinh & 57 & 5.57 & 99 & 9.67 & 115 & 11.23 & 271 & 26.46 \\
\hline & Ethnics & 28 & 2.73 & 8 & 0.78 & 16 & 1.56 & 52 & 5.08 \\
\hline & Total & 85 & 8.30 & 107 & 10.45 & 131 & 12.79 & 323 & 31.54 \\
\hline \multirow[t]{3}{*}{ Total } & Kinh & 360 & 35.16 & 148 & 14.45 & 182 & 17.77 & 690 & 67.38 \\
\hline & Ethnics & 196 & 19.14 & 50 & 4.88 & 88 & 8.59 & 334 & 32.62 \\
\hline & Total & 556 & 54.30 & 198 & 19.34 & 270 & 26.37 & 1024 & 100.00 \\
\hline \multicolumn{2}{|c|}{$\begin{array}{l}\text { The ratio of } \\
\text { ethnic students }\end{array}$} & 196 & 58.68 & 50 & 14.97 & 88 & 26.35 & 334 & 100.00 \\
\hline
\end{tabular}




\subsection{Results of interviews students participating in extracurricular sport training by ethnicity and school}

Out of the total 1024 students in Soc Trang province were interviewed, 690 Kinh students accounting for $67.38 \%$ and 334 ethnic students accounting for 32.62\% (Teacher's Training college 360 Kinh students accounting for 35.16\% and 196 ethnic students accounting for $19.14 \%$, Community college $148 \mathrm{Kinh}$ students accounting for $14.45 \%$. and 50 ethnic students accounting for $4.88 \%$, Vocational College 182 Kinh students accounting for $17.77 \%$ and 88 ethnic students accounting for $8.59 \%$ ).

Out of 334 ethnic students, Teacher's Training college has 196 students accounting for $58.68 \%$, Community college has 50 students accounting for $14.79 \%$, and Vocational college has 88 students accounting for $26.35 \%$.

701 students participated in extracurricular sport training accounting for $68.45 \%$ (419 Kinh students accounting for $40.91 \%$ and 282 ethnic students accounting for $27.54 \%$ ), and 323 students didn't participate in extracurricular sport training accounting for $31.55 \%$ (271 Kinh students accounting for $26.46 \%$ and 52 ethnic minority students accounting for $5.08 \%$ ).

Out of 701 students $(68.45 \%)$ in Soc Trang province participated in extracurricular sport training (Teacher's Training college has 303 Kinh students accounting for 29.59\% and 168 ethnic students accounting for $16.41 \%$, Community college has 49 Kinh students accounting for $4.79 \%$ and 42 ethnic students accounting for $4.10 \%$, Vocational college has 67 Kinh students accounting for $6.54 \%$ and 72 ethnic students accounting for $7.03 \%$ ). Out of 323 students (31.55\%) in Soc Trang province who did not participate in extracurricular training (Teacher's Training college has 57 Kinh students accounting for $5.57 \%$ and 28 ethnic students accounting for $2.73 \%$, Community college has 99 Kinh students accounting for $9.67 \%$ and 08 ethnic students accounting for $0.78 \%$, Vocational college has 115 Kinh students accounting for $11.23 \%$ and 16 ethnic students accounting for $1.56 \%$ ).

701 students (68.45\%) in Soc Trang province participated in extracurricular sport training, the students who practiced regularly consisting of 195 students accounting for 19.04\% (135 Kinh students accounting for 13.18\% and 60 ethnic students accounting for $5.86 \%$ ) and 506 students who sometimes practiced accounting for $49.41 \%$ (284 Kinh students accounting for $27.73 \%$ and 222 ethnic students accounting for $21.68 \%$ ). The comparison of the percentage of ethnic and Kinh students participating in extracurricular sports is shown in Chart 2. 


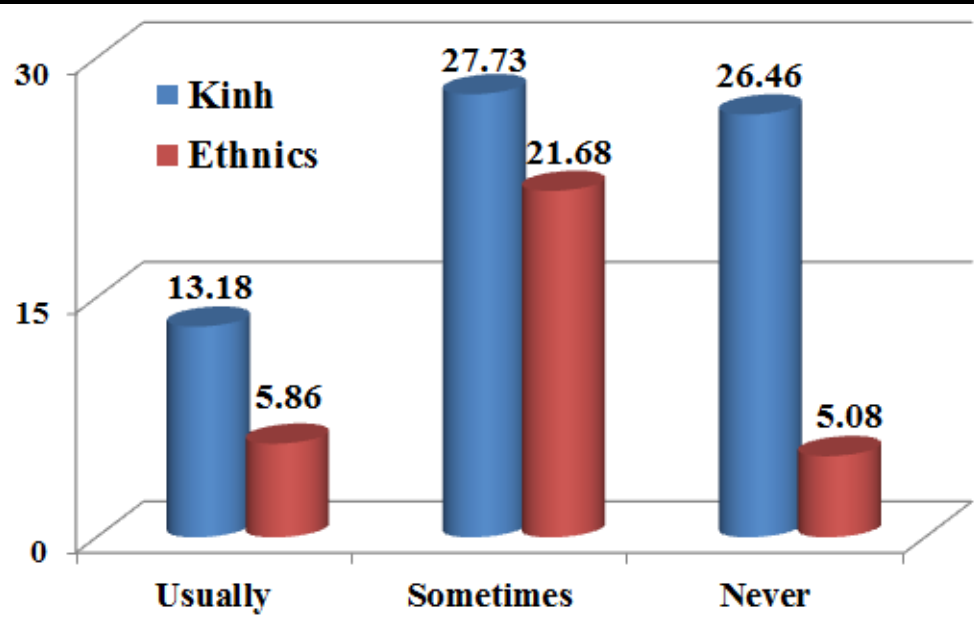

Figure 2: Comparison of percentage of ethnic and Kinh students participating in extracurricular sports

\subsection{The purpose of students when participating in extracurricular sport activities}

The results of the survey on the purposes of students when participating in extracurricular activities are presented in Table 3.

Table 3: Students' goals when participating in extracurricular sport activities $(n=1024)$

\begin{tabular}{|c|l|c|c|c|c|c|c|}
\hline \multirow{2}{*}{ No } & Purpose & \multicolumn{2}{|c|}{ Male } & \multicolumn{2}{c|}{ Female } & \multicolumn{2}{c|}{ Total } \\
\cline { 3 - 8 } & & Quantity & $\mathbf{\%}$ & Quantity & $\mathbf{\%}$ & Quantity & $\%$ \\
\hline 1 & Health training & 139 & 19.83 & 279 & 39.80 & 418 & 59.63 \\
\hline 2 & Entertain & 63 & 8.99 & 94 & 13.41 & 157 & 22.40 \\
\hline 3 & Support the content of main course & 14 & 2.00 & 47 & 6.70 & 61 & 8.70 \\
\hline 4 & Have a good figure & 19 & 2.71 & 27 & 3.85 & 46 & 6.56 \\
\hline 5 & Expand community & 7 & 1.00 & 8 & 1.14 & 15 & 2.14 \\
\hline 6 & Cultivate the will and quality & 0 & 0.00 & 2 & 0.29 & 2 & 0.29 \\
\hline 7 & Become a celerity & 0 & 0.00 & 2 & 0.29 & 2 & 0.29 \\
\hline 8 & Total & 242 & 34.66 & 459 & 65.48 & 701 & 100.0 \\
\hline
\end{tabular}

The results in Table 3 show that among 701 students participating in extracurricular sport activities, the purpose for health training is the highest with 418 students accounting for $59.63 \%$, entertainment 157 students accounting for $22.40 \%$, supporting the content of the main course 61 students accounting for $8.70 \%$; having a good figure 46 students accounting for $6.56 \%$, expanding communication 15 students accounting for $2.14 \%$, training the will and quality is the lowest and becoming a celebrity 2 students accounting for $0.29 \%$.

The highest purpose of Soc Trang students participating in extracurricular sports is shown in Figure 3. 


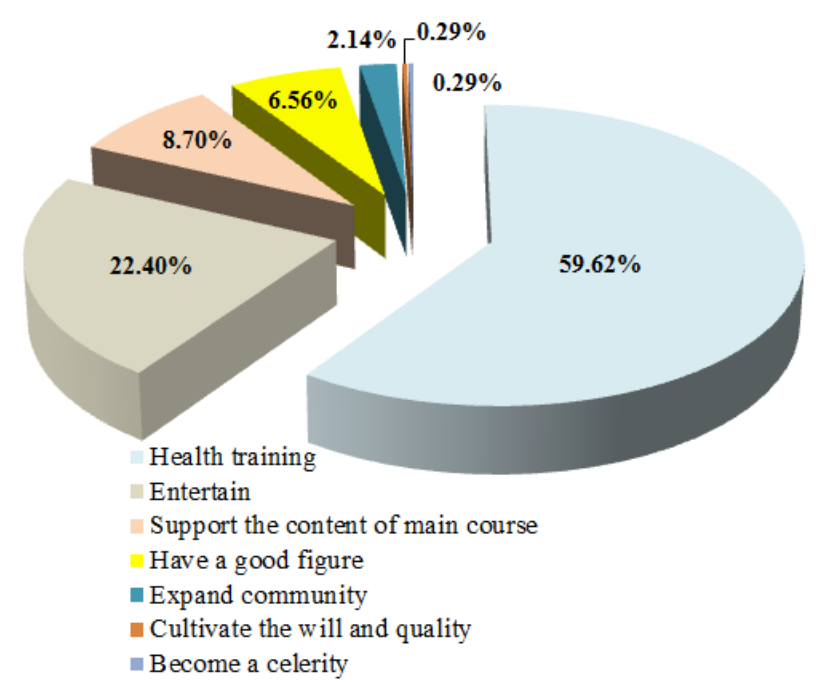

Figure 3: The highest purpose of Soc Trang students participate in extracurricular sports

The reality is that the number of students in Soc Trang province participating in extracurricular sport training is not much $(68.45 \%)$ and the students' practicing diligence in Soc Trang province is very low (19.04\%). The percentage of female students $(44.83 \%)$ participating in exercise is higher than that of male students $(23.64 \%)$. However, if we consider the practicing diligence, the percentage of male students $(10.16 \%)$ is higher than the rate of female students $(8.89 \%)$. In other words, the extracurricular physical activity of students at colleges in Soc Trang province is quite low and has not yet become a habit. This situation is similar to the research results of Nguyen Duc Thanh and Phung Xuan Dung [2], [5].

It can be seen that the number of students in Soc Trang province participating in extracurricular sport training is still low and has not met the target set by the schools' sports and physical education developing project, at least $85 \%$ of students participating in activities regularly. TTNK [7, p.2].

\section{Conclusion}

In 1024 (381 male students accounting for 37.21\%, 643 female students accounting for $62.79 \%$ and 690 Kinh students accounting for $67.38 \%$ and 334 ethnic students accounting for $32.62 \%$ ). Out of the 701 students participated in extracurricular sports accounting for $68.45 \%$ and 323 students who did not participate in extracurricular sport training accounting for $31.55 \%$. Out of the 701 students who participated in extracurricular sport training, 195 students practiced regularly accounting for 19.04\% and 506 students sometimes practiced accounting for $49.41 \%$.

The goal which students took part in extracurricular sports because of health training is the highest 418 students accounting for $59.63 \%$, and the goal of the will and quality training is the lowest and the one of becoming a celebrity 02 students accounting for $0.29 \%$. 


\title{
Conflict of Interest Statement
}

The authors declare no conflicts of interests.

\author{
About the Authors \\ Dang Minh Thanh has been a physical education teacher at Can Tho University, \\ Vietnam.
}

Tran Nam Giao has been a physical education teacher at Vietnam National University Ho Chi Minh City Center for Sport, Vietnam.

Nguyen Quang Vinh is Associate Professor, Academic Affairs, Ho Chi Minh University of Physical Education and Sports, Vietnam. His research interests include physical education, teachers' beliefs and PE curriculum planning.

\section{References}

[1]. Ministry of Education and Training (2008), Decision No. 72/2008/QD-BGDDT dated December 23, 2008 on promulgating Regulations on organization of extracurricular sport activities for students

[2]. Phung Xuan Dung (2017). A study of solutions to improve the effectiveness of extracurricular sports activities for students of Hanoi University of Sports and Education, PhD thesis in Education, Institute of Sports Science

[3]. Pham Duy Khanh (2015). Research on measures to organize extra-curricular sports activities to improve physical fitness for students at Tay Bac University, Master's Thesis in Education, Bac Ninh University of Sport and Sports

[4]. Le Van Lam - Pham Xuan Thanh (2008). Physical Education Curriculum in Schools, Sports Publishing House, Hanoi

[5]. Nguyen Duc Thanh (2013). Developing the content and form of organizing extracurricular sports activities of students of some universities in Ho Chi Minh City. PhD thesis in Education, Institute of Sports Science

[6] Prime Minister (2010). Decision No. 2198/QD-TTg dated December 3, 2010 on the approval of the Sport Development Strategy in Vietnam until 2020, pp.9,12

[7]. Prime Minister (2016). Decision 1076/QD-TTg, dated June 17, 2016, Approving the project on development of physical education and school sports for the period 2016-2020, with orientation to 2025. 
Dang Minh Thanh, Tran Nam Giao, Nguyen Quang Vinh

Creative Commons licensing terms

Authors will retain the copyright of their published articles agreeing that a Creative Commons Attribution 4.0 International License (CC BY 4.0) terms will be applied to their work. Under the terms of this license, no permission is required from the author(s) or publisher for members of the community to copy, distribute, transmit or adapt the article content, providing a proper, prominent and unambiguous attribution to the authors in a manner that makes clear that the materials are being reused under permission of a Creative Commons License. Views, opinions and conclusions expressed in this research article are views, opinions and conclusions of the author(s). Open Access Publishing Group and European Journal of Physical Education and Sport Science shall not be responsible or answerable for any loss, damage or liability caused in relation to/arising out of conflict of interests, copyright violations and inappropriate or inaccurate use of any kind content related or integrated on the research work. All the published works are meeting the Open Access Publishing requirements and can be freely accessed, shared, modified, distributed and used in educational, commercial and non-commercial purposes under a Creative Commons attribution 4.0 International License (CC BY 4.0). 